\title{
Effect of High-fat Diet on Peritoneal Macrophage Immunocompetence in C57/BL6 Mice
}

\author{
Jun-hyun Jeong, Hee-geun Park and Wang-lok Lee*
}

Department of Sports Science, Chungnam National University, Daejeon 305-764, Korea

Received April 3, 2013 /Revised June 19, 2013 /Accepted June 19, 2013

\begin{abstract}
This study was to investigate the effect of high-fat diet on macrophage immunocompetence in C57BL/ 6 mice. C57BL/ 6 male mice ( 4 weeks aged, $n=16$ ) were divided into two groups. HD groups fed high-fat diet ( $45 \%$ of fat) and ND groups fed chow diet (10\% of fat). Peritoneal macrophages were obtained from each mouse intra-peritoneal by sterile lavage method. Macrophage were stimulated with $1 \mathrm{\mu g} / \mathrm{ml}$ of lipopolysaccharide (LPS) for $24 \mathrm{hr}$. Body weight was significantly increased by high-fat diet. Macrophage phagocytosis of HD was significantly lower than that of ND. After $24 \mathrm{hr}$ of LPS stimulation, NO, IL-1 $\beta$ and IFN- $\gamma$ production of HD were significantly lower than those of ND. There were no significant differences in the production of TNF- $a$ and IL-12 between HD and ND. These findings suggest that high fat diet-induced obesity is associated with decreased Immunocompetence and antigen-stimulated sensitivity of peritoneal macrophage, and lower production of NO, IL-1 $\beta$ and IFN- $\gamma$ may contribute to these changes.
\end{abstract}

Key words : Cytokine, high fat diet, macrophage, nitric oxide, phagocytosis

\section{서 론}

불규칙적인 생활 습관은 면역계의 항상성을 유지하지 못하 고 면역 능력을 저하 시킨다. 특히, 식이 습관은 인간의 생명 유지와 건강에 중요한 역할을 수행하지만, 과도한 영양 섭취 는 에너지 대사의 불균형을 초래하여 비만을 유도한다[25]. 비 만상태에서 지방조직은 잉여 에너지를 저장할 뿐만 아니라, 렙틴(leptin)과 TNF (tumor necrosis factor) 그리고 각종 인터 루킨(interleukin)을 비롯한 다양한 사이토카인을 분비함으로 써 생리적 활성화 조절역할을 수행한다[13]. 또한, 과도한 지방 조직은 지방세포의 비정상적인 유전자 발현과 신호전달의 체 계이상과 더불어 사이토카인 분비이상을 초래하며, 백혈구수 와 호중구수 및 $\mathrm{T}$ 임파구 아형을 증가시켜 $\mathrm{T}$ 세포와 B 세포의 기능을 감소시키는 등 면역기능 저하의 원인을 제공한다[16]. 특히 Trayhurn과 Woods [22]는 염증유발 및 항염증의 양면성 을 모두 가진 것으로 알려진 interleukin-6 (이하 IL-6) 사이토 카인이 지방조직에서 증가된다는 것을 보고하였으며, Shoelson 등[20]의 연구에서는 지방조직이 tumor necrosis factor-a (TNF-a)의 분비를 증가시켜 결국 인슐린 저항성 및 당뇨병 유병률을 높인다고 보고하였다. 더욱이, 체지방의 증

\footnotetext{
*Corresponding author

Tel : +82-42-821-6458, Fax : +82-42-823-0387

E-mail : leewl@cnu.ac.kr

This is an Open-Access article distributed under the terms of the Creative Commons Attribution Non-Commercial License (http://creativecommons.org/licenses/by-nc/3.0) which permits unrestricted non-commercial use, distribution, and reproduction in any medium, provided the original work is properly cited.
}

가는 IL-6 및 TNF- $a$ 와 같은 염증 유발성 요인의 증가를 통해서 근육량 감소의 요인으로 작용하며, 간에서의 C-반응성 단백 (c-reactive protein, CRP) 분비를 자극하여 관상동맥의 죽상경 화증 유발에 직접적인 영향을 미치는 것으로 알려져 있다[18].

비만과 대식세포의 면역반응에 관한 선행연구들을 고찰 해보면, Matarese 등[12]은 유전적으로 비만인쥐에서 대식세 포의 식균작용이 낮았으며, 지질다당류(LPS)로 자극한 대식 세포에서 분비되는 전염증성 사이토카인(TNF-a와 IL-1B)의 발현이 낮았다는 연구결과를 보고하였다. 또한, Loffreda 등 [10]의 연구에서 유전적 비만쥐의 복강 대식세포에서의 식균 작용은 정상체중쥐의 식균능력에 비해 유의하게 낮았으며, 대식세포의 강력한 자극물질인 지질다당류(LPS)로 자극한 후 분비되는 사이토카인(TNF-a, IL-6, IL-12)의 발현이 유의 하게 낮은 결과를 보여주며, 유전적 비만쥐의 경우 선천성 면역반응이 손상되어 외부 자극물질(LPS)에 대한 대식세포 의 활성도가 낮은 것이라 보고하였다.

고지방식이에 의해 유도된 비만과 대식세포 면역반응에 대 한 선행 연구에서도, Hang 등[6]은 동물연구에서 고지방 식이 ( $40 \%$ 지방)를 하는 집단이 정상 식이 집단에 비해 대식세포의 TNF-a mRNA 발현이 증가했다고 보고하였고, Amar 등[1]은 지방함량이 $60 \%$ 인 고지방식이로 유도된 비만쥐가 정상체중 쥐에 비해 동맥경화인자로 알려진 치주 병원성세균(P. gingivalis)에 대한 감염 비율이 높았으며, 감염 후에도 LPS로 자극 한 대식세포에서 분비되는 TNF-a, interleukin-12 (IL-12), in-

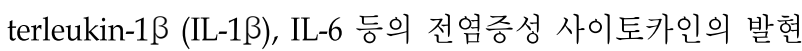
이 유의하게 감소한다는 결과를 통하여 고지방식이에 의한 비만이 대식세포의 외부항원에 대한 활성도를 감소시켜 면역 
계에 부적절한 조절을 야기한다고 보고하였다.

이상에서와 같이 비만과 면역반응에 관한 다수의 연구에서 비만이 대식세포의 면역능력을 억제시키는 것을 검증하고 있 으나, 대식세포의 기능을 평가하는 식균작용과 식균작용에 영 향을 미치는 것을 알려진 산화질소와 사이토카인 생성량을 비교-분석한 연구는 부족한 실정이다. 그러므로 비만으로 인 한 대식세포의 면역반응을 이해하기 위해서는 대식세포 식균 작용과 그와 연관된 산화질소의 생성량을 분석하고, 더불어 대식세포에서 분비되는 염증성 사이토카인과 Th1/Th2 사이 토카인의 발현을 알아보는 것이 필요하다. 따라서 본 연구는 C57/BL6 생쥐를 대상으로 지방 함량이 $45 \%$ 인 고지방 사료를 이용하여 5 주간 고지방 식이를 처치하여 복강내 대식세포의 식균작용과 대식세포 자극제인 LPS와 INF- $\gamma$ 처치 후 분비되 는 산화질소 및 사이토카인의 변화 양상을 규명하고자 한다.

\section{재료 및 방법}

\section{실험동물}

실험동물은 4 주령의 C57BL/6 종으로 수컷 생쥐 총 16 마리 를 (주)오리엔트바이오에서 분양 받아 그룹당 8 마리씩 고지방 식이 그룹과 일반 식이 그룹으로 배치하였다. 실험 동물의 사 육 환경은 평균 온도 $22 \pm 2^{\circ} \mathrm{C}$, 습도 $50 \pm 5 \%$ 의 조건으로, 주 · 야 순환은 12 시간(06:00-18:00 주간시간) 주기로 유지하였으며, 한 케이지 당 4 마리씩 사육하였고 사료와 물은 충분히 공급하 였다. 실험동물의 취급은 실험동물윤리위원회에 계획서를 제 출하고 승인받았으며(승인번호 CNU-00202), 위원회의 동물 실험 취급 규정에 따라 사육하고 실험하였다.

\section{비만유도 및 식이 처치}

비만의 유도는 선행연구(Shapiro 등[19])에 따라 고지방 식 이 사료(45\% fat, rodent diet with high fat, \# D12451)를 이용 하여 5 주간 고지방 식이를 자유섭취토록 하였다. 일반식이집 단은 일반사료 $(15 \% \mathrm{fat})$ 를 제공하였고, 섭취한 사료의 양은 매 일 기록하였으며, 생쥐별 1 일 섭취량은 제한하지 않았다.

\section{복강 대식세포 분리 및 배양}

희생 3일전 마우스 복강에 3\% thioglycollate (DIFCO, Detroit, USA) $2 \mathrm{ml}$ 를 복강에 주사하여 대식세포를 유도하였 다. 마우스를 경추탈골법에 의해 희생시키고 $5 \mathrm{ml}$ 주사기 (Greenject-5, Doo Won Co., Korea)를 이용하여 복강에 $5 \mathrm{ml}$ 의 RPMI 1640 (GIBCO, USA) 배지를 주입하고 2 3분간 부드럽 게 마사지한 후 $5 \mathrm{ml}$ 주사기로 복강세포를 수확하는 것을 3회 반복하여 약 10-15 ml의 복강세포를 추출하였다. 회수한 복강 세포는 tryphan blue dye를 이용하여 세포수를 확인한 후,
$1 \times 10^{6} \mathrm{cells} / \mathrm{ml}$ 농도로 희석하여, 세포액 $1 \mathrm{ml}$ 을 24 well plate (NUNC, Denmark)에 분주하고 $37^{\circ} \mathrm{C}, 5 \% \mathrm{CO}_{2}$ 세포 배양기에 서 2 시간 배양 후 항생제와 FBS가 함유된 배지를 교환하면서 비부착 세포를 제거하였다.

복강에서 수집된 세포에서 대식세포의 비율을 확인하기 위 해 수집된 복강 세포를 $1 \times 10^{6}$ cells을 두 개의 $15 \mathrm{ml}$ tube에 $5 \times 10^{5}$ cells로 나누어 대식세포의 특이적 세포 표면 단백질인 CD11b antibody (BD Biosciences, San Diego, CA) 1 씨를 한 개의 튜브에만 섞어 $4^{\circ} \mathrm{C}$ 에서 30 분간 배양 후 유세포 분석기 (FACS Caliber Flow Cytometry; Becton dickinson, San Jose, USA)를 이용하여 측정하였다.

\section{식균작용 측정}

대식세포의 식균 작용을 측정하기 위하여 $1 \times 10^{6} \mathrm{cells} / 150$ $\mu \mathrm{l}$ 농도로 $1 \mathrm{ml}$ 튜브에 두 개를 만들어 dextran (MW 70,000, Sigma, USA)를 처치한 후 통제군은 $4^{\circ} \mathrm{C}$ 에서, 처치군은 $37^{\circ} \mathrm{C}$, $5 \% \mathrm{CO}_{2}$ incubator에서 2시간 배양 후 남아있는 FITC (fluorescein isothiocyanate)를 씻어내고 유세포 분석기(FACS Caliber Flow Cytometry; Becton dickinson, San Jose, USA)로 측정하였다. 식균지수(phagocytosis index)는 $4^{\circ} \mathrm{C}$ 로 배양한 결 과로 $37^{\circ} \mathrm{C}$ 로 배양한 평균값을 나누어 수치화하였다.

\section{산화질소(nitric oxide)와 사이토카인(cytokine) 측정}

분주한 대식세포 $\left(1 \times 10^{6}\right.$ cells/well $)$ 에 대식세포 자극제인 lipopolysaccharide (LPS, Sigma Chemical Co., St. Louis, MO) 를 $1 \mathrm{\mu g} / \mathrm{ml}$ 농도로 처치한 후 24 시간 동안 $37^{\circ} \mathrm{C}, 5 \% \mathrm{CO}_{2}$ incubator에서 배양한 후 상등액을 이용하여 측정하였다. 산화 질소는 Griess assay를 이용하였고, 사이토카인(IL-13, IL-12, IFN- $\gamma$, TNF-a)은 ELISA assay kit (eBioscience, USA)를 이용 하여 측정하였다.

\section{자료처리}

모든 자료는 SPSS의 통계 package를 이용하여 각 그룹별 측정항목에 대한 평균 및 표준오차를 산출하였다. 고지방식이 군과 일반식이군의 체중과 대식세포의 식균작용 그리고 산화 질소와 사이토카인 생성량에 대한 항목별 유의차 분석은 독립 $\mathrm{t}$ 검증법(independent t-test)으로 검증하였으며, 모든 통계적 유의수준은 $a=0.05$ 를 기준으로 하였다.

\section{결과 및 고찰}

\section{복강 대식세포 확인}

복강에서 분리한 복강세포에서 대식세포의 비율을 확인하 기 위해 CD11b antibody를 이용하여 그룹별로 한 마리씩 네 차례에 걸쳐 대식세포를 확인한 결과 $88.77 \%$ 가 대식세포임을 확인하였다(Fig. 1A, 1B). 

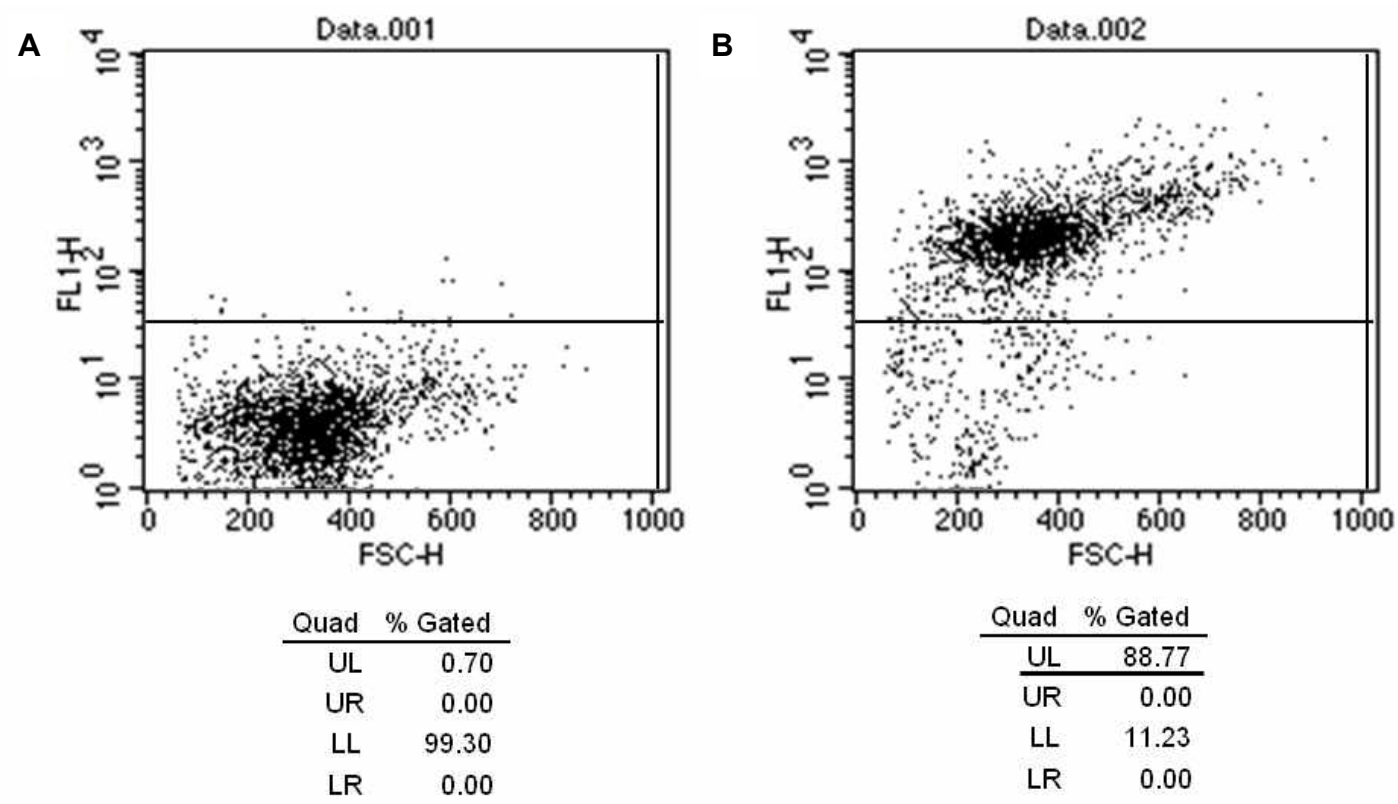

Fig. 1. CD11b expression of the peritoneal macrophages by flowcytometery. Purity of macrophage was measured above $88 \%$. A: incubation without CD11b antibody, B: incubation with CD11b antibody.
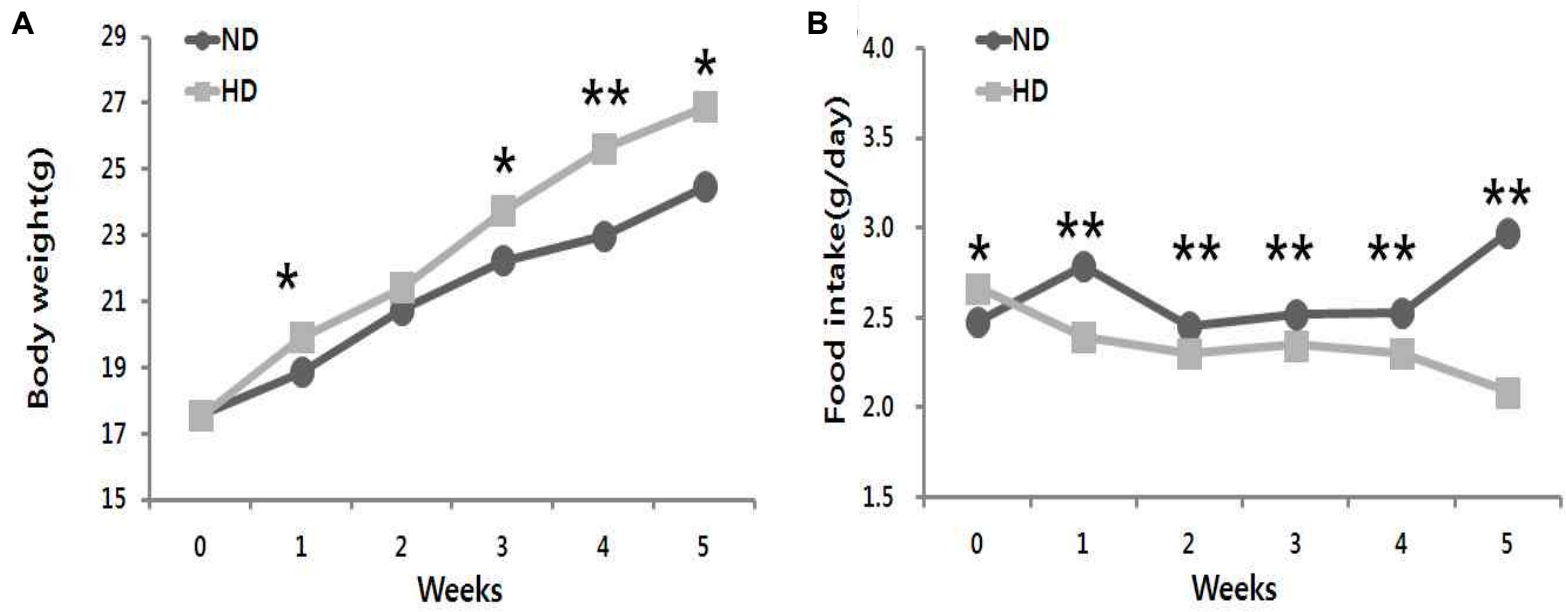

Fig. 2. Changes of body weights (A) and food intakes (B) in high-fat diet induced obese C57BL/6 mice for 5 weeks. Values are expressed as the mean $\pm \mathrm{SD}$ of 8 mice in each group by independent $t$-test with normal diet group (ND) and high-fat diet group (HD). *; $p<0.05, * * ; p<0.01$, significant difference to ND.

\section{체중과 식이 섭취량의 변화}

시기에 따른 체중의 변화는 $\mathrm{HD}$ 그룹이 $\mathrm{ND}$ 그룹에 비해 1 주 차부터 3주, 4 주, 5 차까지 유의하게 증가하였고, 식이 섭취량 은 섭취 첫 주에는 $\mathrm{HD}$ 그룹이 유의하게 높았으나, 2주, 3주, 4 주, 5 주차에는 $\mathrm{ND}$ 그룹이 높게 관찰 되었다(Fig. $2 \mathrm{~A}, 2 \mathrm{~B})$. 체 중은 $\mathrm{HD}$ 그룹이 $\mathrm{ND}$ 그룹에 비해 의미 있게 증가하였으나, 오 히려 식이섭취량은 $\mathrm{HD}$ 그룹이 유의하게 감소하여, 고지방식 이를 할 경우 체중은 증가하지만 식이 섭취량에는 차이가 없 다는 선행연구들과는 일치하지 않았다 $[1,4]$. 이러한 결과는
본 연구에서 사용한 고지방식이로 인하여 식이 섭취량은 줄었 지만 총 칼로리 섭취가 증가함에 따라 체중이 유의하게 증가 된 것으로 사료된다.

\section{복강 대식세포의 식균작용}

복강 대식세포의 식균작용 결과 $\mathrm{ND}$ 그룹과 $\mathrm{HD}$ 그룹 모두 $4{ }^{\circ} \mathrm{C}$ 배양 $(\mathrm{M}=2.70)$ 에서 $37^{\circ} \mathrm{C}$ 로 배양 $(\mathrm{M}=7.49)$ 한 후, 대식세포 에서의 식작용이 증가하였고(Fig. $3 \mathrm{~A}, 3 \mathrm{~B})$, 식균지수 $\left(4^{\circ} \mathrm{C}\right.$ 수 치로 $37^{\circ} \mathrm{C}$ 수치를 나눈 값)에 대한 결과 $\mathrm{HD}$ 그룹이 $\mathrm{ND}$ 그룹 

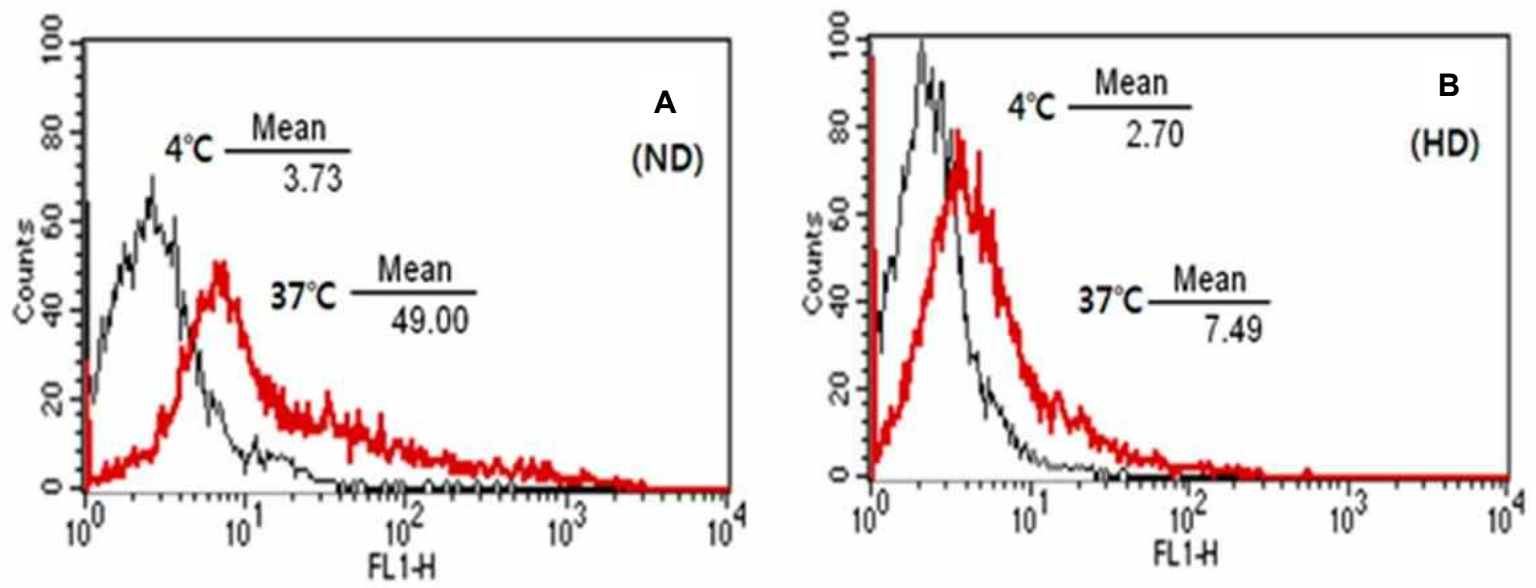

Fig. 3. Dextran-FITC of the peritoneal macrophages by flowcytometery.

Table 1. The results on phagocytosis index of peritoneal macrophage

\begin{tabular}{ccccc}
\hline Groups & $\mathrm{M} \pm \mathrm{SD}$ & $\mathrm{t}$ & $\mathrm{df}$ & $\mathrm{p}$ \\
\hline $\mathrm{ND}$ & $6.5 \pm 2.1$ & 2.44 & \multirow{2}{*}{6} & $0.050^{*}$ \\
HD & $3.8 \pm 0.6$ & & \\
\hline
\end{tabular}

Values are expressed as the mean \pm SD of 8 mice in each group by independent $t$-test with normal diet group (ND) and high-fat diet group (HD).

*; $p<0.05$, significant difference to ND.

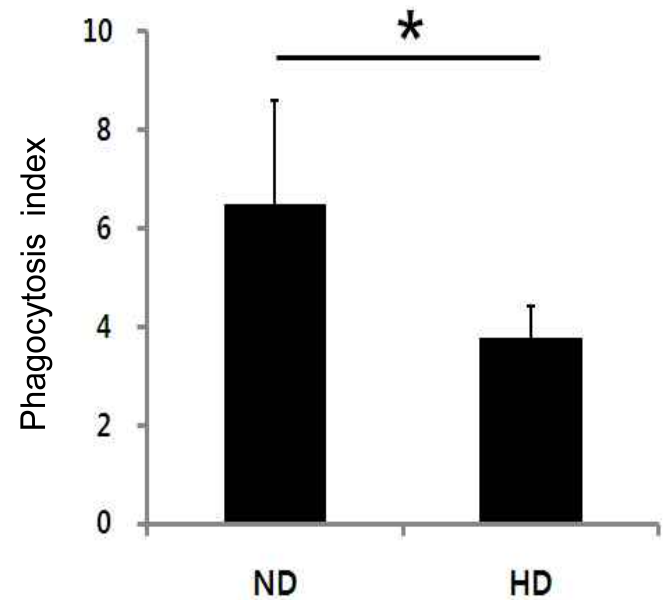

Fig. 4. Phagocytosis index of peritoneal macrophage in High fat diet-induced obese mice for 5 weeks.

Phagocytic Index, treatment (incubation in $37^{\circ} \mathrm{C}$ )/control (incubation in $4^{\circ} \mathrm{C}$ ). ${ }^{*} ; p<0.05$, significant difference to ND.

에 비해 통계적으로 의미 있게 감소되었다 $(p=0.05)$ (Table 1 과 Fig. 4). 이러한 결과는 비만으로 인한 과도한 지방조직의 축적은 대식세포가 지방으로 침윤되는 현상을 증가시키고, 이러한 침윤이 복강 내 대식세포의 수를 감소시키는 결과를 초래하여 외부 항원에 대한 대식세포의 식균작용을 저하시 킨다는 선행연구와 일치된다 $[12,16]$.
복강 대식세포의 산화질소 발현량

복강 대식세포에서 발현되는 산화질소 발현량은 비항원 대 식세포에서 차이가 나타나지 않았으나, 항원 자극한 대식세포 산화질소 생성량은 $\mathrm{HD}$ 그룹이 $\mathrm{ND}$ 그룹에 비해 낮은 경향성이 관찰되었으며, 비항원 자극과 항원 자극 산화질소 발현 비율 에서는 $\mathrm{HD}$ 그룹이 $\mathrm{ND}$ 그룹에 비해 유의하게 감소 되었다 (Table 2와 Fig. 5A, 5B). 이는 유전된 비만쥐와 고지방 식이 유도 비만 생쥐의 복강 대식세포가 정상체중쥐에 비해 iNOS 에 의한 $\mathrm{NO}$ 등 살균분자의 분비가 감소되어 대식세포의 박테 리아 살상능력과 식균 작용이 억제 되었다는 선행 연구와 일 치하는 결과이다[11, 14]. 외부 항원을 포식한 대식세포는 이를 살균하는데 필요한 산화질소의 발현량을 증가시킴에도 불구 하고[12], 본 연구에서 5주간의 고지방 식이가 대식세포의 식 균작용과 산화질소 발현비율 모두에서 유의하게 감소하는 결 과를 보여주었다. 이러한 결과는 고지방식이에 의한 지방축적 이 대식세포의 항원에 대한 민감도을 감소시켜 초기 대응 능 력을 억제시킨 것으로 사료된다.

한편, 대식세포의 산화질소의 생성량은 IL-1ß, TNF-a 등과 같은 전염증 사이토카인과도 관계가 깊으며, 이는 대식세포의 두 가지 활성화 기전으로 설명 되어 진다. 첫 번째 신호는 Th1 세포에 의해서 생산되는 특징적인 사이토카인(IFN- $\gamma$ )에 의 해서 대식세포가 활성화되고, 대식세포가 IFN- $\gamma$ 에 반응하도 록 하는 두 번째 신호는 $\mathrm{T}$ 세포 표면의 $\mathrm{CD} 40$ 리간드가 대식세 포의 $\mathrm{CD} 40$ 과 상호작용하여 전달된다. 결과적으로 대식세포 
Table 2. The results on nitric oxide production of peritoneal macrophage

$(\mathrm{pg} / \mathrm{ml})$

\begin{tabular}{|c|c|c|c|c|c|}
\hline & Groups & $\mathrm{M} \pm \mathrm{SD}$ & $\mathrm{t}$ & $\mathrm{df}$ & $\mathrm{p}$ \\
\hline \multirow{2}{*}{ Non stimulation } & ND & $76.8 \pm 25.5$ & \multirow{2}{*}{-0.05} & \multirow{2}{*}{13} & \multirow{2}{*}{0.963} \\
\hline & HD & $77.4 \pm 21.9$ & & & \\
\hline \multirow{2}{*}{ LPS stimulation } & ND & $413.4 \pm 58.7$ & \multirow{2}{*}{2.10} & \multirow{2}{*}{12} & \multirow{2}{*}{0.057} \\
\hline & $\mathrm{HD}$ & $326.0 \pm 92.9$ & & & \\
\hline \multirow{2}{*}{$\%$ stimulation } & ND & $540.5 \pm 98.8$ & \multirow{2}{*}{2.89} & \multirow{2}{*}{12} & \multirow{2}{*}{$0.014^{*}$} \\
\hline & HD & $421.5 \pm 46.4$ & & & \\
\hline
\end{tabular}

Values are expressed as the mean $\pm \mathrm{SD}$ of 8 mice in each group by independent $\mathrm{t}$-test with normal diet group (ND) and high-fat diet group (HD). N; number, M; mean, SD; standard deviation

*; $p<0.05,{ }^{* *} ; p<0.01$, significantly difference with HD.
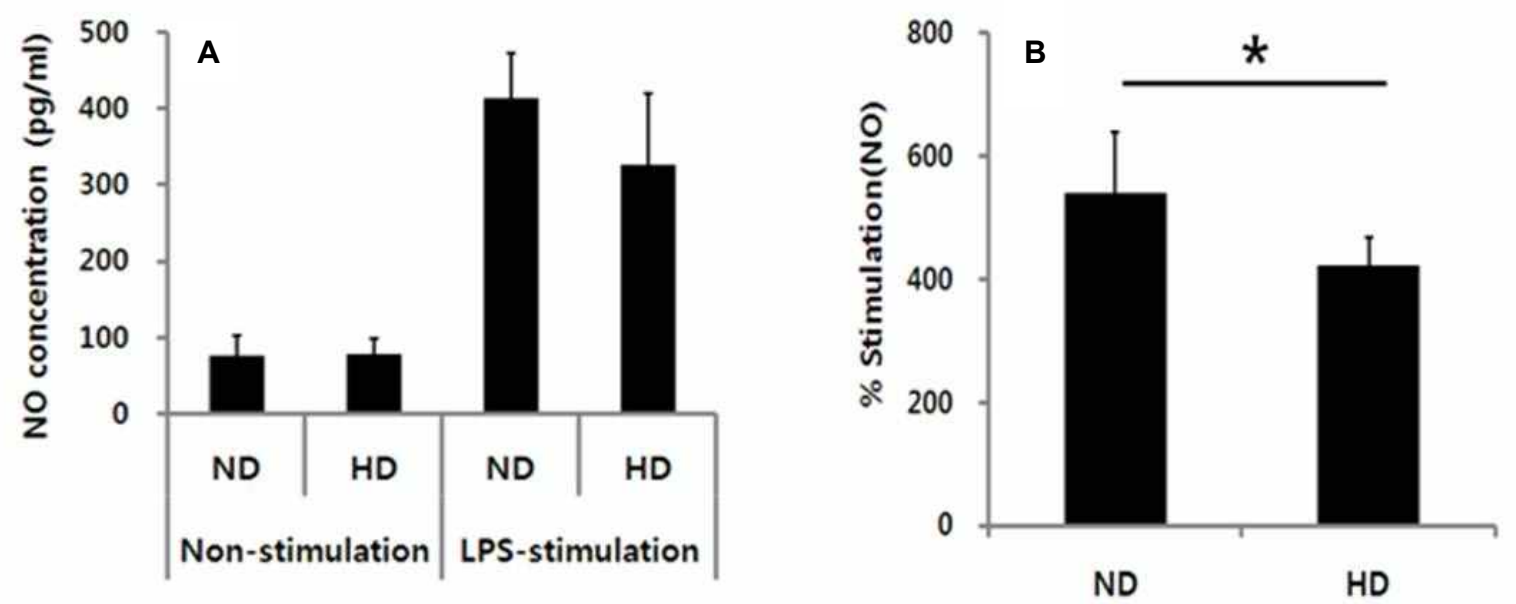

Fig. 5. Nitric oxide production of peritoneal macrophage in high fat diet-induced obese mice for 5 weeks. A, Constitutive production(without antigenic stimulation) and LPS-stimulated nitric oxide production of macrophages (LPS $1 \mu \mathrm{g} / \mathrm{ml}$ ) for 24 $\mathrm{hr}$ incubation. B, LPS-induced stimulation percentage (with 100 corresponding to the constitutive production in the absence of LPS activation). *; $p<0.05$, significant difference to ND.

의 활성화는 $\mathrm{CD} 40$ 와 $\mathrm{TNF}$ 수용체의 표현을 증가시키게 되고, 이것이 대식세포의 감수성을 증가시킨다[7]. 또한, TNF- $a$ 는 활성화된 대식세포 자신에 의해서 생산되는데 IFN- $\gamma$ 와 상승 작용으로 활성화의 수준을 증가시키고 결국 살균분자로 작용 하는 산화질소 등의 발현을 증가시킨다[17]. 이러한 선행연구 들은 본 연구에서 제시한 사이토카인의 결과들과도 밀접한
관련이 있음을 보여준다.

\section{복강대식세포의 IL-1 발현량}

IL-1 1 는 T세포와 자연살해세포 활성과 같은 사이토카인 네 트워크에서 중요한 역할을 수행하는 대식세포 분비 사이토카 인이며[2], 외부 항원을 감지한 대식세포는 IL-1 $\beta$ 을 분비하여

Table 3. The results on IL-1 $\beta$ production of peritoneal macrophage

$(\mathrm{pg} / \mathrm{ml})$

\begin{tabular}{|c|c|c|c|c|c|}
\hline & Groups & $\mathrm{M} \pm \mathrm{SD}$ & $\mathrm{t}$ & $\mathrm{df}$ & $\mathrm{p}$ \\
\hline Non stimulation & $\begin{array}{l}\text { ND } \\
\text { HD }\end{array}$ & $\begin{array}{l}60.3 \pm 9.5 \\
60.5 \pm 10.1\end{array}$ & -0.06 & 14 & 0.956 \\
\hline LPS stimulation & $\begin{array}{l}\text { ND } \\
\text { HD }\end{array}$ & $\begin{array}{r}159.5 \pm 19.8 \\
84.3 \pm 11.5\end{array}$ & 8.04 & 10 & $0.000^{* *}$ \\
\hline$\%$ stimulation & $\begin{array}{l}\text { ND } \\
\text { HD }\end{array}$ & $\begin{array}{l}253.7 \pm 17.5 \\
108.9 \pm 6.1\end{array}$ & 16.27 & 10 & $0.000^{* *}$ \\
\hline
\end{tabular}

Values are expressed as the mean \pm SD of 8 mice in each group by independent $t$-test with normal diet group (ND) and high-fat diet group (HD). N; number, M; mean, SD; standard deviation

*; $p<0.05$, **; $p<0.01$, significantly difference with HD. 

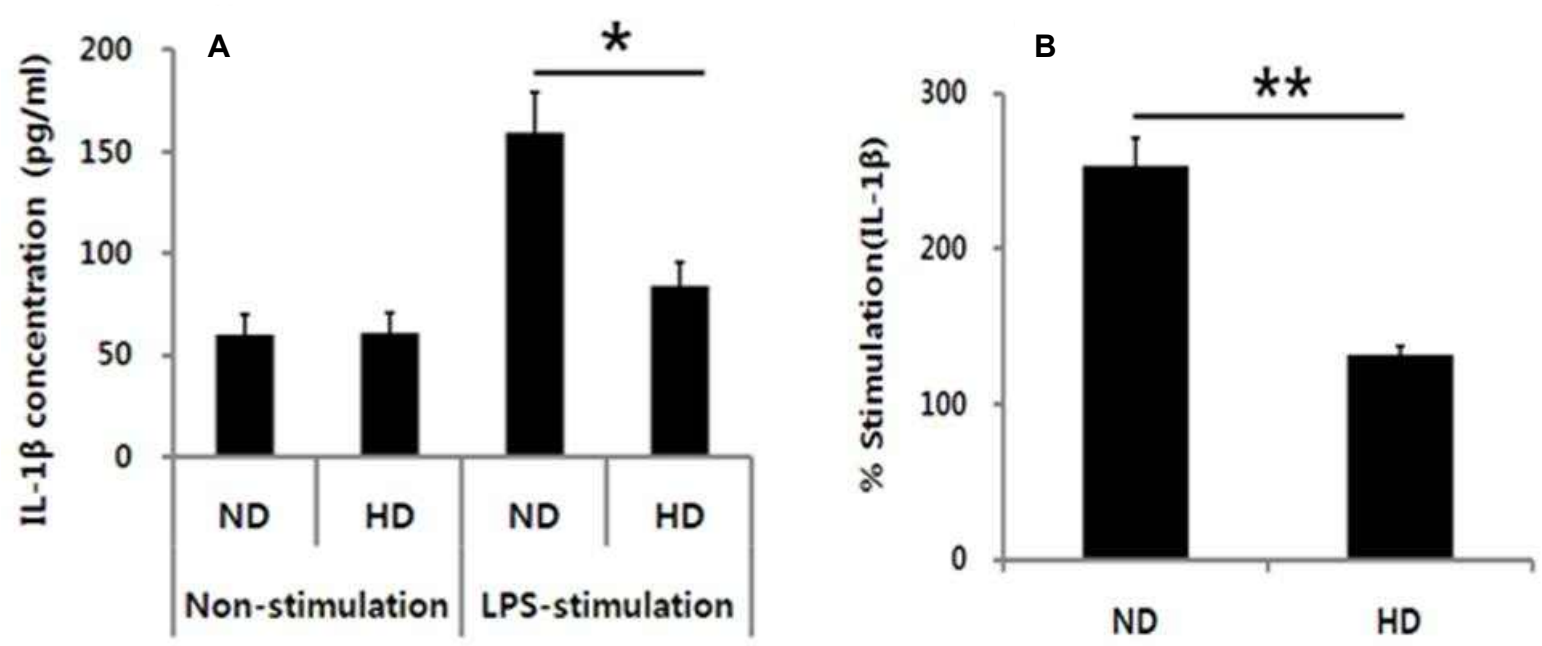

Fig. 6. IL-1 $\beta$ production of peritoneal macrophage in high fat diet-induced obese mice for 5 weeks. A, Constitutive production(without antigenic stimulation) and LPS-stimulated nitric oxide production of macrophages (LPS $1 \mu \mathrm{g} / \mathrm{ml}$ ) for $24 \mathrm{hr}$ incubation. $\mathrm{B}$, LPS-induced stimulation percentage (with 100 corresponding to the constitutive production in the absence of LPS activation). *; $p<0.05,{ }^{* *} ; p<0.01$, significant difference to ND.

비특이 염증반응을 개시하는 초기 면역반응 물질이다. 또한 전염증성 사이토카인은 조직 손상시 숙주의 방어를 위해 중요 한 신호를 전달하지만, 지나치게 과다 분비 시 항염증성 사이 토카인(IL-4, IL-10)들과의 불균형을 가져와 숙주의 생존을 위 협한다고 알려져 있다[21].

본 연구에서 복강 대식세포의 IL-1 발현량은 차이가 나타

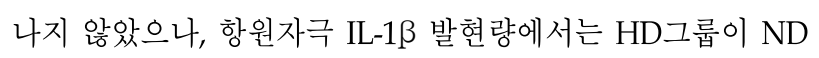
그룹에 비해 의미 있게 감소되었고, 비항원과 항원 자극 대식 세포 산화질소 발현 비율에서도 $\mathrm{HD}$ 그룹이 $\mathrm{ND}$ 그룹에 비해 유의하게 감소되었다(Table 3과 Fig. 6A, 6B). 이러한 결과는 유전자조작 비만 생쥐에서 LPS로 자극한 후 대식세포에서 분 비되는 전염증성 사이토카인(TNF-a와 IL-1 $\beta)$ 의 발현이 낮았 다는 결과와[12], 유전된 비만쥐의 복강 대식세포는 정상 체중 쥐에 비해 대식세포의 강력한 자극물질인 LPS로 자극한 후 분비되는 염증 사이토카인(TNF-a, IL-6, IL-12)의 발현이 유의 하게 낮았다는 보고[10]와 고지방식이에 의한 비만이 대식세
포의 외부항원에 대한 민감도를 감소시켜 항원 자극 사이토카 인의 억제와 산화질소의 발현을 억제하여 면역계에 부적절한 조절을 야기한다는 보고[1]들과 일치하는 결과이다. 본 연구에 서 항원 자극 IL-1 $\beta$ 생성량이 $\mathrm{HD}$ 그룹에서 유의하게 감소된 것은, 고지방 식이에 의한 비만이 지방조직에서 염증성 사이 토카인(TNF-a, IL-1 $\beta$ 등)을 지속적으로 분비하게 되고, 이런 낮은 수준의 염증상태에 만성적으로 노출된 대식세포는 항원 에 대한 친수성이 손상되었기 때문이라고 사료된다.

\section{복강대식세포의 TNF- $a$ 발현량}

복강 대식세포에서 발현되는 TNF- $a$ 발현량은 통계적 유의 한 차이를 발견하진 못하였으나(Table 4와 Fig. 7A, 7B), 자극 비율에서는 $\mathrm{HD}$ 그룹이 $\mathrm{ND}$ 그룹에 비해 감소하는 경향을 보여 주었다. 이러한 결과는 유전자조작 비만 생쥐에서 LPS로 자극 한 후 대식세포에서 분비되는 전염증성 사이토카인(TNF- $a$ 와 IL-13)의 발현이 낮았다는 결과[14]와 고지방식이에 의한 비만

Table 4. The results on TNF- $\alpha$ production of peritoneal macrophage

$(\mathrm{pg} / \mathrm{ml})$

\begin{tabular}{cccccc}
\hline & Groups & $\mathrm{M} \pm \mathrm{SD}$ & $\mathrm{t}$ & $\mathrm{df}$ & $\mathrm{p}$ \\
\hline \multirow{2}{*}{ Non stimulation } & $\mathrm{ND}$ & $68.1 \pm 18.0$ & -0.29 & \multirow{2}{*}{0.779} \\
& $\mathrm{HD}$ & $71.1 \pm 18.2$ & \multirow{2}{*}{1.45} & \multirow{2}{*}{0.12} & \multirow{2}{*}{0.172} \\
\hline \multirow{2}{*}{ LPS stimulation } & $\mathrm{ND}$ & $397.7 \pm 72.1$ & 2.10 & \multirow{2}{*}{0.062} \\
\hline \multirow{2}{*}{$\%$ stimulation } & $\mathrm{HD}$ & $330.3 \pm 99.2$ & $627.7 \pm 100.7$ & $50.8 \pm 108.3$ &
\end{tabular}

Values are expressed as the mean \pm SD of 8 mice in each group by independent $t$-test with normal diet group (ND) and high-fat diet group (HD). N; number, M; mean, SD; standard deviation *; $p<0.05$, **; $p<0.01$, significantly difference with HD. 

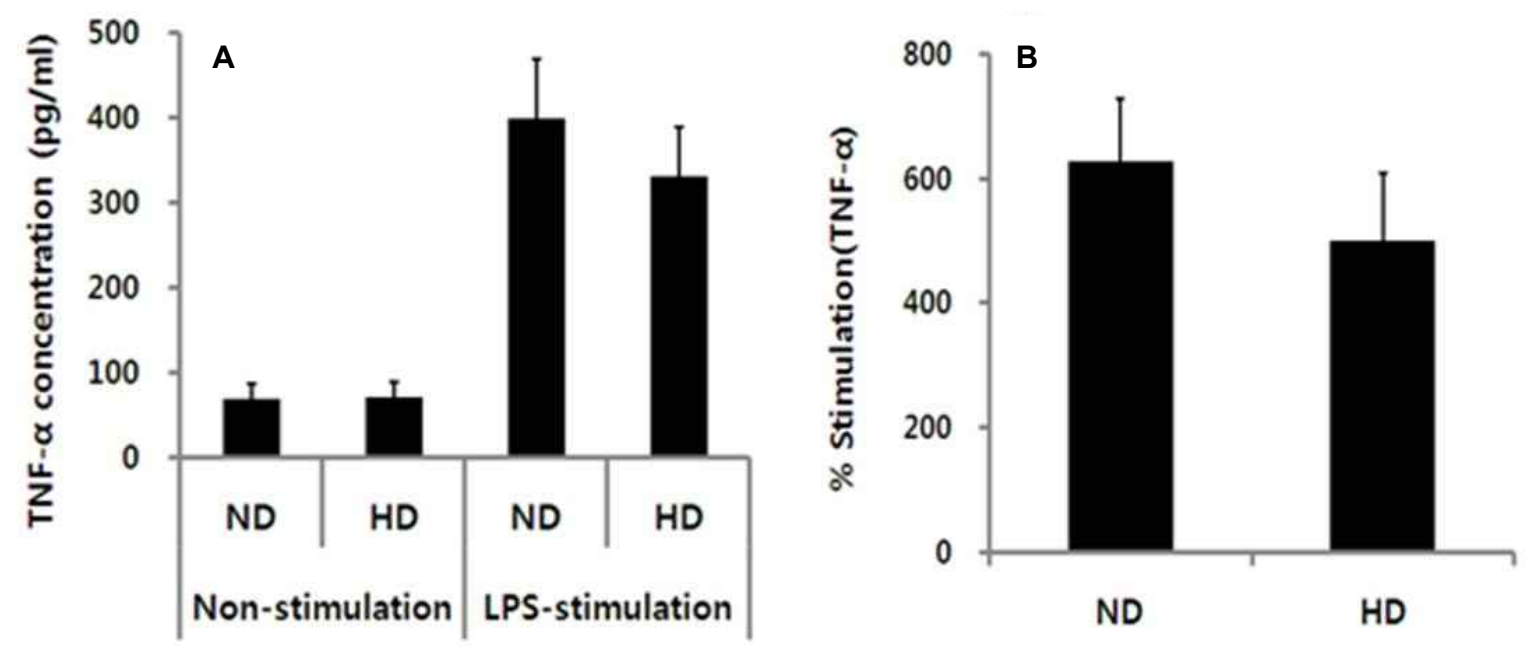

Fig. 7. TNF-a production of peritoneal macrophage in high-fat diet induced obese mice for 5 weeks.

A, Constitutive production (without antigenic stimulation) and LPS-stimulated nitric oxide production of macrophages (LPS $1 \mathrm{\mu g} / \mathrm{ml}$ ) for $24 \mathrm{hr}$ incubation. B, LPS-induced stimulation percentage (with 100 corresponding to the constitutive production in the absence of LPS activation).

이 대식세포의 외부항원에 대한 활성도를 감소시켜 면역계에 부적절한 조절을 야기한다고 보고한 선행연구 결과를[1] 부분 적으로 지지한다. 그러나 본 결과에서 LPS를 자극한 대식세포 분비 TNF-a 생성량이 LPS를 자극하지 않은 것에 비해 증가되 었음에도 불구하고 집단간에 의미있는 차이를 나타나지 않은 것은 고지방식이 기간이 다소 짧았기 때문인 것으로 사료된 다. 보다 더 장기간 실시한다면 대식세포 분비 TNF-a 생성양 은 유의하게 변화할 것이라 사료된다.

\section{복강대식세포의 IL-12 발현량}

활성화된 대식세포와 수지상세포에서 주로 생산된다고 알 려진, IL-12는 세포 내 미생물에 대한 초기 선천면역반응에서 숙주를 보호하는 주요한 매개자 역할을 수행하고, 적응면역반 응을 증진하는 등 선천면역과 적응면역 사이의 중요한 연결 고리 역할을 수행한다고 알려져 있다[23]. 본 연구에서 복강 대식세포에서 발현되는 IL-12 발현량은 통계적 유의한 차이를
발견하지 못하였으며(Table 5와 Fig. 8A, 8B), 이는 비만 대상 연구에서 대식세포의 항원 자극 IL-12 발현량이 의미 있게 감 소된다는 선행연구의 결과 $[1,10,15]$ 들과 일치하지 않았다.

한편, 선행연구에서 사용한 고지방식이의 기간과 함량을 살 펴보면, 지방함량 $60 \%$ 사료로 16 주[1], $20 \%$ 로 24 주 [8], 35\%로 10 주[3], $56 \%$ 로 6주[9], 45\%로 6주[24]로 각각 상이했다. 따라 서 고지방 식이의 차이에 따라 IL-12의 발현양은 차이를 가지 는 것으로 사료된다.

\section{복강대식세포의 IFN- $\gamma$ 발현량}

본 연구에서 나타난 복강 대식세포에서 발현되는 IFN- $\gamma$ 발현량은 비항원 대식세포에서 차이가 나타나지 않았으나, 항 원 자극 대식세포에서는 $\mathrm{HD}$ 그룹이 ND그룹에 비해 의미 있게 감소되었고, 비항원과 항원자극의 산화질소 발현 비율에서도 $\mathrm{HD}$ 그룹이 ND그룹에 비해 유의하게 감소되었다(Table 6과 Fig. 9A, 9B). 이러한 결과는, Cordero 등[5]이 유전자 조작 비

Table 5. The results on IL-12 production of peritoneal macrophage

$(\mathrm{pg} / \mathrm{ml})$

\begin{tabular}{cccccc}
\hline & Groups & $\mathrm{M} \pm \mathrm{SD}$ & $\mathrm{t}$ & $\mathrm{df}$ & $\mathrm{p}$ \\
\hline \multirow{2}{*}{ Non stimulation } & $\mathrm{ND}$ & $158.6 \pm 14.1$ & -0.84 & \multirow{2}{*}{0.421} \\
& $\mathrm{HD}$ & $171.8 \pm 35.8$ & \multirow{2}{*}{1.98} & \multirow{2}{*}{11} & 0.074 \\
\hline \multirow{2}{*}{ LPS stimulation } & $\mathrm{ND}$ & $244.3 \pm 23.2$ & -0.86 & \multirow{2}{*}{11} & 0.411 \\
\hline \multirow{2}{*}{$\%$ stimulation } & $\mathrm{HD}$ & $220.3 \pm 20.6$ & $139.0 \pm 23.5$ & $131.9 \pm 22.7$ &
\end{tabular}

Values are expressed as the mean \pm SD of 8 mice in each group by independent $t$-test with normal diet group(ND) and high-fat diet group(HD). N; number, $\mathrm{M}$; mean, $\mathrm{SD}$; standard deviation *; $p<0.05$, **; $p<0.01$, significantly difference with HD. 

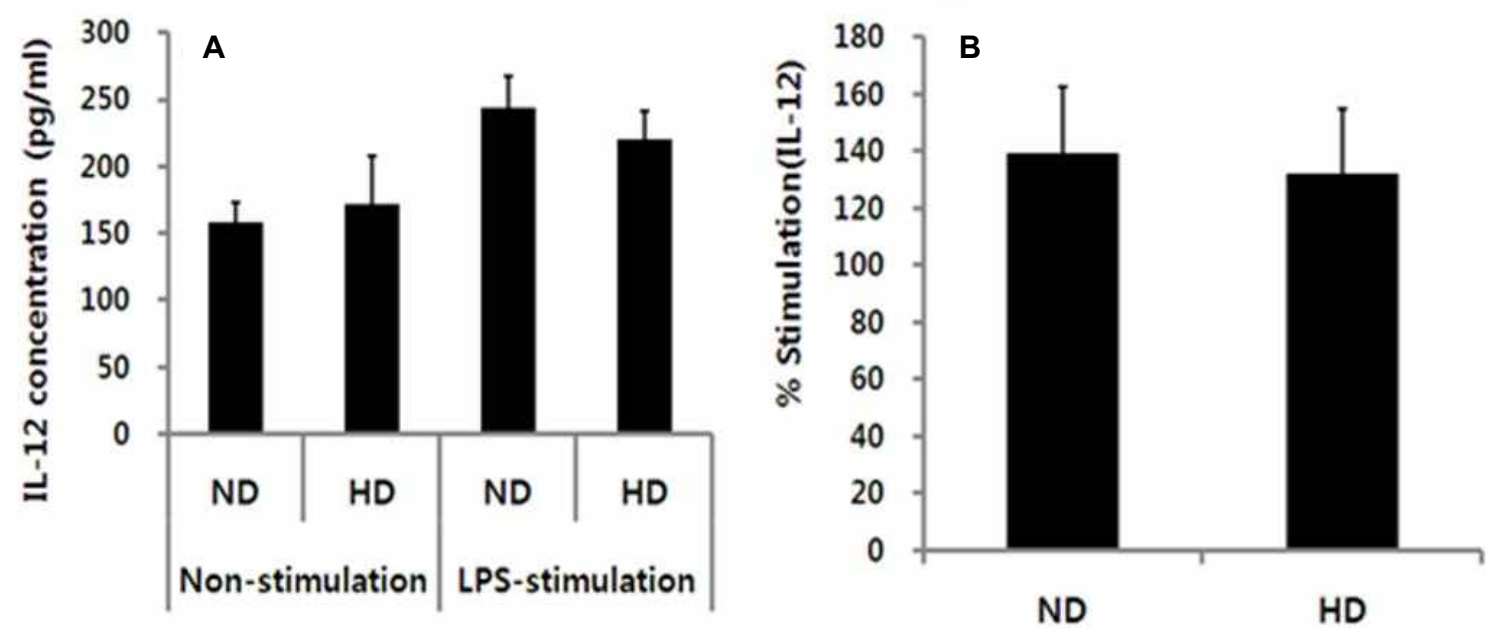

Fig. 8. IL-12 production of peritoneal macrophage in high-fat diet induced obese mice for 5 weeks.

A, Constitutive production (without antigenic stimulation) and LPS-stimulated nitric oxide production of macrophages (LPS $1 \mathrm{\mu g} / \mathrm{ml}$ ) for $24 \mathrm{hr}$ incubation. B, LPS-induced stimulation percentage (with 100 corresponding to the constitutive production in the absence of LPS activation).

Table 6. The results on IFN- $\gamma$ production of peritoneal macrophage $(\mathrm{pg} / \mathrm{ml})$

\begin{tabular}{|c|c|c|c|c|c|}
\hline & Groups & $\mathrm{M} \pm \mathrm{SD}$ & $\mathrm{t}$ & $\mathrm{df}$ & $\mathrm{p}$ \\
\hline \multirow{2}{*}{ Non stimulation } & ND & $152.7 \pm 19.5$ & \multirow{2}{*}{0.49} & \multirow{2}{*}{12} & \multirow{2}{*}{0.635} \\
\hline & $\mathrm{HD}$ & $148.1 \pm 15.9$ & & & \\
\hline \multirow{2}{*}{ LPS stimulation } & ND & $184.2 \pm 6.8$ & \multirow{2}{*}{5.45} & \multirow{2}{*}{12} & \multirow{2}{*}{$0.000^{* *}$} \\
\hline & HD & $160.5 \pm 8.9$ & & & \\
\hline \multirow{2}{*}{$\%$ stimulation } & ND & $122.1 \pm 13.3$ & \multirow{2}{*}{2.48} & \multirow{2}{*}{12} & \multirow{2}{*}{$0.029^{*}$} \\
\hline & $\mathrm{HD}$ & $108.9 \pm 6.1$ & & & \\
\hline
\end{tabular}

Values are expressed as the mean $\pm \mathrm{SD}$ of 8 mice in each group by independent $\mathrm{t}$-test with normal diet group(ND) and high-fat diet group(HD). N; number, M; mean, SD; standard deviation

*; $p<0.05$, **; $p<0.01$, significantly difference with HD.
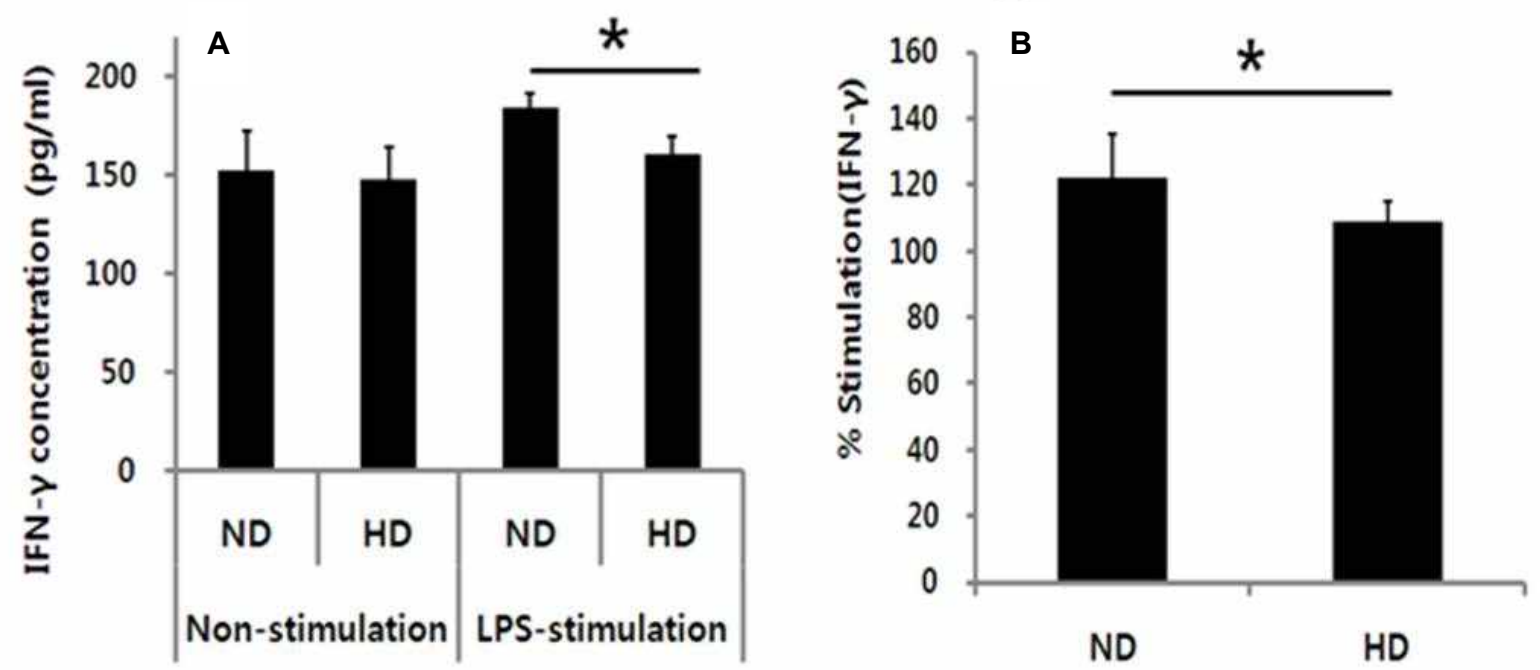

Fig. 9. IFN- $\gamma$ production of peritoneal macrophage in high-fat diet induced obese mice for 5 weeks. A, Constitutive production (without antigenic stimulation) and LPS-stimulated nitric oxide production of macrophages (LPS $1 \mu \mathrm{kg} / \mathrm{ml}$ ) for $24 \mathrm{hr}$ incubation. B, LPS-induced stimulation percentage (with 100 corresponding to the constitutive production in the absence of LPS activation). ${ }^{*} ; p<0.05$, significant difference to ND. 
만 모델(obese Zucker rats)을 사용한 연구에서 LPS로 자극한 대식세포에서 IFN- $\gamma$ 의 생성량이 비만쥐가 정상쥐에 비해 유 의하게 감소되었으며, 자극 비율에서도 비만쥐가 유의하게 낮 았다는 선행연구와 일치하는 결과이다. 또한, 본 연구의 IL-1 $\beta$ 발현량과 유사한 결과를 나타내어 고지방식이에 의한 비만이 대식세포의 외부항원에 대한 친수성를 감소시켜 면역능력을 억제하기 때문일지도 모른다.

본 연구결과를 종합하여 볼 때, 5 주간의 고지방식이가 대식 세포의 식균작용과 산화질소, IL-1 1 , IFN- $\gamma$ 의 생성량을 감소 시킴으로써, 대식세포의 면역능력을 억제하여 항원에 대한 친 수성을 감소시키는 결과를 관찰하였다.

\section{감사의 글}

이 논문은 2012년도 정부(교육과학기술부)의 재원으로 한 국연구재단의 지원을 받아 수행된 기초연구사업임(No. 2012R1A1A2009551).

\section{References}

1. Amar, S., Zhou, Q., Shaik-Dasthagirisaheb, Y. and Leeman, S. 2007. Diet-induced obesity in mice causes changes in immune responses and bone loss manifested by bacterial challenge. Proc Natl Acad Sci USA 104, 20466-20471.

2. Balkwill, F. 1993. Cytokines in health and disease. Immunol Today 14, 149-150.

3. Bedoui, S., Velkoska E., Bozinovski, S., Jones, J., Anderson, G. and Morris, M. 2005. Unaltered TNF-a production by macrophages and monocytes in diet-induced obesity in the rat. J Inflammation 2, 2

4. Chang, H. K., Park, H. G., Jeong, J. H. and Lee, W. L. 2011. Effects of moderate exercise training on splenocyte inflammatory cytokine production in high fat diet induced obese mice. J Life Sci 21, 1176-1182.

5. Cordero, L. M., Garcia, J. J., Giraldo, E., Fuente, M., Manso, R. and Ortega, E. 2009. Influence of exercise on the circulating levels and macrophage production of IL-1b and IFN-r affected by metabolic syndrome: an obese Zucker rat experimental animal model. Eur J Appl Physiol 107, 535-543.

6. Hang, S., Kokoeva, M., Inouye, K., Tzameli, I., Huali, Y. and Flier, J. 2006. TLR4 links innate immunity and fatty acid induced insulin resistance. $J$ Clin Invest 116, 3015-3025.

7. Kindt, T. J., Goldsby, R. A., Osborne, B. A. and Kuby, J. 2000. Immunology, pp. 147-148, $4^{\text {th }}$ ed., W. H. Freeman \& Co, NY, USA.

8. Kim, M., Choi, M. and Han, S. 2011. High fat diet-induced obesity leads to proinflammatory response associated with higher expression of NOD2 protein. Nutr Res Pract 5, 219-223.

9. Kizaki, T., Maegawa, T., Sakurai, T., Ogasawara, J. E., Ookawara, T., Oh-ishi, S., Izawa, T., Haga, S. and Ohno, H. 2011. Voluntary exercise attenuates obesity-associated in- flammation through ghrelin expressed in macrophages. Biochem Biophys Res Commun 413, 454-459.

10. Loffreda, S., Yang, S. Q., Lin, H. Z., Karp, C. L., Brengman, M. L., Wang, D. J., Klein, A. S., Bulkley, G. B., Bao, C., Noble, P. W., Lane, M. D. and Diehl, A. M. 1998. Leptin regulates proinflammatory immune responses. FASEB J12, 57-65.

11. Macmicking, J. Q. X. and NAthan, C. F. 1997. Nitric oxide and macrophage function. Annu Rev Immunol 15, 323-350.

12. Matarese, G. 2000. Leptin and the immune system: how nutritional status influences the immune response. Eur Cytokine Netw 11, 7-14.

13. Matsuzawa, Y., Funalhashi, T. and Nakamura, T. 1999. Molecular mechanism of metabolic syndrome $X$ : contribution of adipocytokines adipocyte-derived bioactive substance. Ann J Clin Nutr 52, 426-430.

14. Moriguchi, S., Katto, M., Sakai, K., Yamamoto, S. and Shimizu, E. 1998. Exercise training restore decreased cellular immune function in obese Zucker rats. J Appl Physiol 84, 311-317.

15. Moshyedi, A. K., Josephs, M. D., Abdalla, E. K., Mackay, S. L., Edwards, C. K., Copeland, E. M. and Moldawe, L. L. 1998. Increased leptin expression in mice with bacterial peritonitis is partially regulated by TNF-a. Infect Immun 66, 1800-1802.

16. Nieman, D. C., Henson, D. A., Nehlsen-Cannarella, S. L, Ekkens, M., Utter, A. C., Butterworth D. E. and Fagoaga, O. R. 1999. Influence of obesity on immune function. J Am Diet Assoc 99, 294-299.

17. Parham, P. 2005. The Immune System, pp. 6-7, $2^{\text {nd }}$ ed, Garland Science. NY, USA.

18. Roudeff, R. 2004. Sarcopenic obesity: The confidnece of two epidemics. Obes Res 12, 887-888.

19. Shapiro, M. E. 2001. Effects of treatment of C57BL/6J mice fed high vs. low fat diets with metformin or rosiglitazone on adiposity, food intake, hyperglycemia and insulin resistance. Endocrine Society Annual Meeting, Poster Session.

20. Shoelson, S. E., Lee, J. and Goldfine, A. B. 2006. Inflammation and insulin resistance. J Clin Invest 116, 1793-1801.

21. Tanaka, S., Inoue, S., Isoda, F., Waseda, M., Ishihara, M., Yamakawa, T., Suglyama, A., Takamura, Y. and Okuda K. 1993. Impaired immunity in obesity: suppresed, but reversible lymphocyte responsiveness. Int J Obes 17, 631-636.

22. Trayhurn, P. and Wood, I. S. 2005. Signaling role of adipose tissue: adipokines and inflammation in obesity. Biochem Soc Trans 33, 1078-1081.

23. Trinchieri, G. 2003. Interleukin-12 and the regulation of innate resistance and adaptive immunity. Nat Rev Immunol 3, 133-146.

24. Vieira, V. J., Valentine, R. J., Wilund, K. R., Antao, N., Baynard, T. and Woods, J. A. 2009. Effects of exercise and low-fat diet on adipose tissue inflammation and metabolic complications in obese mice. AmJ Physiol Endocrinol Metab 96, 1164-1171.

25. Wellen, K. E. and Hotamisligil, G. S. 2005. Inflammation, stress, and diabetes. J Clin Invest 115, 1111-119. 
초록 : 고지방 식이가 C57/BL6생쥐의 복강대식세포 면역능력에 미치는 영향

정준현 · 박희근 · 이왕록*

(충남대학교 스포츠과학과)

본 연구는 5 주간의 고지방 식이(45\% 지방)가 복강 대식세포의 면역 반응에 미치는 효과를 분석하였다. $\mathrm{C} 57 \mathrm{BL} / 6$ 마우스(4주령, $\mathrm{N}=16)$ 를 2집단으로 나누어 고지방 식이집단 $(\mathrm{HD}, \mathrm{N}=8)$ 은 $45 \%$ 지방 함량 고지방식이를 정상 식이집단( $\mathrm{ND}, \mathrm{N}=8)$ 은 정상식이( $10 \%$ 지방)를 5 주간 실시하였다. 복강 대식세포는 복강세척법을 이용하여 획득하였으며, LPS (lipopolysaccharide, $1 \mathrm{\mu g} / \mathrm{ml}, 24$ 시간)를 이용하여 배양하였다. 체중은 고지방식이 후 유의하 게 증가하였으며, LPS 처치 후 HD그룹의 산화질소, IL-1 $\beta$ 및 IFN- $\gamma$ 생성량은 ND그룹에 비하여 유의하게 낮았 다. 그러나 두 집단에서 TNF-a와 IL-12의 생성량은 유의한 변화가 없었다. 이러한 결과는 비만 시 대식세포의 식균작용, 산화질소, IL-1 $\beta$ 및 IFN- $\gamma$ 생성량이 낮아짐에 따라 면역반응과 항원자극 감수성이 저하되는 것으로 사료된다. 